\title{
An Islamic Perspective of Marketing
}

\author{
K. M. Anwarul Islam ${ }^{1}$ \\ Orobah Ali Barghouthi ${ }^{2}$ \\ ${ }^{1}$ Department of Business Administration, The Millennium University, Dhaka, Bangladesh \\ ${ }^{2}$ Faculty of Business and Economics, Department of Banking \& Finance, Alquds University, Abu Dis, Palestine. \\ Correspondence: Faculty of Business and Economics, Department of Banking \& Finance, Alquds \\ University,Abu Dis, Palestine, E-mail: obargothi@hotmail.com
}

Received: November 24, $2017 \quad$ Accepted: November 28, $2017 \quad$ Online Published: December 14, 2017

\begin{abstract}
The point of this paper was happened to think about whether there is anything, for example, "Islamic showcasing." Her argu $\neg$ ment began from the thought of inefficient use/lavishness in Islam: "Israf." She offered her clarification on how promoting today (which basically is contemporary advertising) centers on commercialization and "cre $\neg$ ating a need." The Webster's lexicon characterizes industrialism as "the concept that a regularly extending utilization of merchandise is favorable to the economy" which in Islam is "excess/Israf," and is profoundly dismissed. Just in this way, on the off chance that promoting depends on commercialization, quite a bit of what she said is genuinely like how individuals see the presence of Islamic advertising as an idea. To an expansive degree, this couldn't be opposing this idea.
\end{abstract}

Keywords: Marketing, Ethics, Islamic Perspective.

\section{Introduction}

Just to elucidate what my short yet amazing (she was doubtlessly awed!) discussion with her was about, I totally concur with her perspective that if showcasing exercises are about overindulgence of sustenance, attire, and extravagance merchandise then it has no place in the Islamic sys ᄀtem. Be that as it may, this additionally makes understanding advertising from the Islamic point of view significantly more critical. Islamic promoting is one of the man $a$ agement ideas where variety in divergence with contemporary mar $\neg$ keting is a lot bigger than numerous different ideas in the executives.

Presently hold up a moment, the dilemma isn't "promoting," it's consum?erism. Islam has permitted the utilization everything being equal and comforts of life, and does not request that anybody surrender any such things. The Holy Quran says:

Muhammad say: Who has forbidden the adornment of Allah which He has brought forth for His servants, and to use the good things of His providing? Say: These on the Day of Resurrection will be only for those who were faithful in the life of this world.(Quran 7: 32) 


\section{2, Data Analysis}

Islam notes wastage of food as a very important subject, in a multifaceted meaning. Hence both wastage and overconsumption are not only against the principles of economic fairness; these are repudiated because of their injurious effects on one's health. The Quran says:

\section{Eat and drink but be not prodigal.(Quran 7: 31)}

Therefore the interpretation is not that Islam asks believers to abstain from fine drinks and food; nonetheless, it does restrict overindulgence. At another place the Quran says:

O you who believe! Eat of the good things with which we have provided you, and give thanks to Allah.(Quran 2: 172)

Further analyzing the verse above, the keyword is "pure"; hence the starting point is "Halal," that is, abiding by the law of permissibility. If concepts are scrounged from contemporary marketing, then within the sphere of Islamic marketing "product" becomes the primary factor. The foremost rule is "permissible business delivering allowable products," whereby accentuating that Halal is not merely a brand element; instead it is part of a belief system and moral code of conduct, integral to daily living.

Need refinement could mean better infant formula being developed based on research, upcoming dietary requirements as a result of new ailments and syndromes. Hence, the second most important element associated with the product is "research and development (R\&D)."

The example above explicates how the cycle is self-sufficient and ever expandable with the focus ultimately being "justojo," that is, research that constantly works on identifying need refinement. The domino effect of product development as a result of need refinement is enhanced quality. What must not be disregarded in this process is creativity. Interestingly, advanced research can also encompass artistic quality. This is of the utmost importance in creating healthy competition. Look at the verse below from the Holy Quran:

O Children of Adam! Wear your beautiful apparel at every time and place of prayer; eat and drink, but waste not by excess, for Allah does not love those who waste.(Quran 7: 31)

In the above-mentioned verse, the use of an adjective such as "beautiful" shows the approval of creativity and the emphasis on "every time" and then specific mentioning of "place of prayer" stresses there is no time and space limit on use of good apparel. This may be a matter of independent debate nevertheless; we all agree beauty begins with cleanliness. Thus, even if one cannot commercially afford the most beautiful apparel, fine looking clothing that is clean is the expected attire Allah (SWT) commands human beings to be dressed in.

Both the above discussion and the concept of vertical product development signify the value of "product" in the Islamic marketing framework. Products that purely focus on "wants" do not adhere to Islamic principles, and hence are deemed inappropriate to the Islamic marketing function.

Note to remember: To reinforce, the prelude to the above discussion is that, criteria of a product to be "Halal."

It is judicious to insinuate that quality also encompasses weight of the product, as mentioned in the Holy Quran:

Fill the measure when you measure and weigh with a right balance, that is proper and better in the 
end.(17: 35)

This verse implies the significance of weight not just for a physical product; the time value and experience offered of service is just as important.

\section{Conclusion}

The talk in the section features that the level of fluctuation between Islamic advertising ideas and western/contemporary market-ing is a lot bigger than in other administration ideas, for example, HRM, etc; the preeminent being that Islamic showcasing does not bolster the idea of commercialization, in light of the fact that in a general sense Islam is against overาspending, "Israf." This is obvious in the agreeable item advancement in Islam where additional items should concentrate on quality instead of simple enthusiastic highlights. That is, the Islamic item advancement process ought to be verרtically disposed for a need until the point that the need is refined because of new fragments emerging. Estimating in Islam must be defended dependent on the "cost of produc $\neg$ tion." Promotion is fundamental to Islamic advertising as it conveys a much big $\neg$ ger point than simply speaking to and luring potential clients. The key objective is to begin at the specific essential dimension of instructing individuals on the different needs as clarified in the Islamic writing.

\section{References}

Aabed, A. (2006). A study of Islamic leadership theory and practice in K-12 Islamic schools in Michigan.(Doctoral dissertation), Brigham Young University.

Abdul-Rauf, M. (1984). A Muslim's Reflection on Democratic Capitalism. Washington, DC: American Enterprise Institute for Public Policy Research.

Abuznaid, S. A. (2009). Business ethics in Islam: The glaring gap in practice.International Journal of Islamic and Middle Eastern Finance and Management 2(4), 278-288.

Al-Jibouri, Y. (2013). Nahjul-Balagha: Path of Eloquence (Vol. 2). Bloomington: Authorhouse.

Allison, S. T., Eylon, D., Beggan, J. K., \& Bachelder, J. (2009). The demise of leadership: Positivity and negativity biases in evaluations of dead leaders. The Leadership Quarterly 20(2), 115-129.

Ash-Shaykh-us-Saduq. (1403 AH). AI-Khisal.Qum, Iran: Mu'assisat-un-Nashr-ul-Islami.

Ash-Shaykh-ut-Tusi. (1390 AH). At-Tahthib.Tehran, Dar-ul-Kutub-il Islamiyyah.

Avolio, B. J., \& Yammarino, F. J. (2002). Transformational and Charismatic Leadership: The Road Ahead. Mahwah, NJ: Erlbaum.

Blanchard, M. C. (2012).Saudi Arabia: Background and U.S.Relations.CRS Report for Congress (7-5700). Retrieved June 8, 2013, from Congressional Research Service http://www.fas.org/sgp/crs/mideast/RL33533.pdf

Bratton, J., \& Gold, J. (2003). Human Resource Management: Theory and Practice (3rd ed.). Hampshire: Palgrave Macmillan.

Burns, J. M. (1978). Leadership.New York, NY: Harper and Row.

Chong, B. S., \& Liu, M-H. (2009). Islamic banking: Interest-free or interest based? Pacific-Basin Finance Journal 17(1), 125-144.

Quran

\section{Copyrights}

Copyright for this article is retained by the author(s), with first publication rights granted to the journal.

This is an open-access article distributed under the terms and conditions of the Creative Commons Attribution license (http://creativecommons.org/licenses/by/4.0/). 